\title{
RECENT DEVELOPMENTS REGARDING THE FREEDOM OF INFORMATION ACT: A "PROLOGUE TO A FARCE OR A TRAGEDY; OR, PERHAPS BOTH"
}

\author{
AMY E. REES \\ INTRODUCTION
}

In its theoretical underpinnings, the Freedom of Information Act (FOIA) ${ }^{1}$ responds to the conflux-or perhaps collision-of the democratic ideals of the founders of American government and the accountability crisis that has characterized that government over the past thirty-five years. Democratic self-rule is predicated on an assumption that the electorate has the knowledge to choose intelligently between different governmental options. Such knowledge is uniformly within governmental control, and FOIA operates as a mechamism by which the public can obtam otherwise shielded information about internal governmental operations. After its enactment in 1966, the need for FOIA became even clearer with the Watergate crisis and the myriad post-Nixon government scandals. With that legacy, FOIA exists today to serve the same interests in public awareness of government activities. The question of whether those interests are actually being furthered, however, is a thorny issue.

In its practical effects, FOIA demonstrates the unwieldimess of modern legislation's interaction with the extensive administrative and regulatory scheme into which the pohtical experiment of the founders has evolved. In a very real sense, particularly in recognition of the extraordimary number of FOIA requests filed each year, FOIA embodies the apphicability in the mid-1990s of the basic definition of our government as one "of the people, by the people, and for the people." The emphatic political rhetoric of James Madison is often cited as the purpose of the Act:

1. 5 U.S.C. $\& 552$ (1988).

2. President Abraham Lincoln, Gettysburg Address (Nov. 19, 1863), reprinted in 2 ABRAHAM LINCOLN: SPEECHES AND WRITINGS (1859-1865) at 536 (P. Fehrenbacher ed., 1989). 
A popular Government, without popular information, or the means of acquiring it, is but a Prologue to a Farce or a Tragedy; or, perhaps both. Knowledge will forever govern ignorance; And a people who mean to be their own Governors, must arm themselves with the power which knowledge gives. ${ }^{3}$

In fact, FOIA has rarely if ever been used as a powerful external check on governmental affairs. Rather, the typical FOIA request is made by a wily civil litigant circumventing traditional discovery rules, a corporate counsel in search of coinpetitors' financial information, or a conspiracy theorist demanding operational files of the Central Intelligence Agency (CIA) on himself or other players in covert intelligence maneuvers in Cuba. ${ }^{4}$

Assuming one of the mine exemptions ${ }^{5}$ to mandatory FOIA

3. Letter from James Madison to W.T. Barry (Aug. 4, 1822), reprinted in THE CoMplete Madison 337 (Saul K. Padover ed., 1953), cited in Elias Clark, Holding Government Accountable: The Amended Freedom of Information Act, 84 YALE L.J. 741, 769 (1975); Patricia M. Wald, The Freedom of Information Act: A Short Case Study in the Perils and Paybacks of Legislating Democratic Values, 33 EMORY L.J. 649, 653 (1984). Also cited in A. Michael's Piano, Inc. v. FTC, 18 F.3d 138, 140-41 (2d Cir.), cert. denied, 115 S. Ct 574 (1994).

4. See, e.g., Maynard v. CIA, 986 F.2d 547 (1st Cir. 1993); infra text accompanying notes 53-69; Sullivan v. CIA, 992 F.2d 1249 (1st Cir. 1993); infra text accompanying notes 70-87; Andrew Blum, Freedom To Battle For Data, NAT'L L.J., Mar. 12, 1990, at 1, 28-29 (noting the furor that was created when NASA files including sensitive information regarding the space shuttle were threatened to be disclosed to Japan through FOIA); Wald, supra note 3, at 665-66 (noting that four out of every five FOIA requests are made by "business executives or their lawyers, who astutely discerned the business value of the information which government obtains from industry while performing its licensing, inspecting, regulating, and contracting functions"); $i d$. at 672-73 (discussing various instances of CIA searches for information with little to no public use, including $\$ 325,000$ spent on one FOIA requestor, Philip Agee, who wanted all records mentioning his name).

5. FOIA exphicitly exempts from disclosure materials that are

(1) (A) specifically authorized under criteria established by an Executive order to be kept secret in the interest of national defense or foreign policy and (B) are im fact properly classified pursuant to such Executive order;

(2) related solely to the internal personnel rules and practices of an agency;

(3) specifically exempted from disclosure by statute (other than section $552 \mathrm{~b}$ of this title), provided that sueh statute (A) requires that the inatters be withheld from the public in such a manner as to leave no discretion on the issue, or (B) establishes particular criteria for withholding or refers to particular types of matters to be withheld;

(4) trade secrets and commercial or financial imformation obtained from a person and privileged or confidential;

(5) inter-agency or intra-agency menoranduns or letters which would not be available by law to a party other than an agency in litigation with the agency;

(6) personnel and medical files and similar files the disclosure of which would constitute a clearly unwarranted invasion of personal privacy; 
disclosure is not invoked by the responding agency, the request is processed. Without assessing either the need or the merit of the request, the system accommodates the inquiry free of charge, devoting significant attention to each demand and accruing extraordinary expense and delay. ${ }^{6}$ The expenditure of time and inoney is all the nore impressive in hight of the relatively few FOIA requests that are actually processed in full, particularly im areas such as CIA files. By claiming that even ineritorious disclosures could unwittingly compromise sensitive intelligence information, the CIA nearly always succeeds in withholding data under the claimed exemption.? Thus, with this near-blanket protection from compelled disclosure, the Agency is effectively removed from the ambit of FOIA's authority.

The consequence of this judicially created, or at minimum judicially sanctioned, removal of CIA information from the Act's

(7) records or information compiled for law enforcement purposes, but only to the extent that the production of such law enforcement records or information (A) could reasonably be expected to interfere with enforcement proceedings, (B) would deprive a person of a right to a fair trial or an impartial adjudication, $(C)$ could reasonably be expected to constitute an unwarranted invasion of personal privacy, (D) could reasonably be expected to disclose the identity of a confidential source, including a State, local, or foreign agency or authority or any private institution which furnished information on a confidential basis, and, in the case of a record or information compiled by criminal law enforcenent authority in the course of a criminal investigation or by an agency conducting a lawful national security intelligence investigation, information furnished by a confidential source, (E) would disclose techniques and procedures for law enforcement investigations or prosecutions, or would disclose guidelines for law enforcement investigations or prosecutions if such disclosure could reasonably be expected to risk circumvention of the law, or (F) could reasonably be expected to endanger the hife or physical safety of any individual;

(8) contamed in or related to examination, operating, or condition reports prepared by, on behalf of, or for the use of an agency responsible for the regulation or supervision of financial institutions; or

(9) geological and geophysical information and data, including maps, concerning wells.

5 U.S.C. \& 552(b) (1988).

6. See generally Michael M. Lowe, Note, The Freedom of Information Act in I993-1994, 43 DUKE L.J. 1282, 1282-86 (1994) (discussing the enormous costs in time and money of FOIA administration).

7. Judge Wald cites a 1981 Senate hearing in which CIA Director Wilham Casey testified that no classified information had been coinpelled from the Agency over its objections during the first 15 years of FOIA's existence, 1966-1981. Wald, supra note 3, at 672. The Deputy Director of the National Security Adıninistration (NSA), Ann Caracristi, stated at the same proceeding that although the NSA had never had disclosure effected, the affidavits prepared in response to hitigation challenging its claimed exemption as well as the in camera inspections and admissions were actually even more revealing of intelligence data than the requested information itself. Id. at 672 n.99. 
scope is that, as far as the CIA is concerned, the purpose of FOIA is thwarted. If, as under Madison's analysis, the public needs access to information at the heart of its government's dealings, then CIA documents are a prime example of information that is essential to a genuine understanding of the workings of the government yet is otherwise completely concealed from popular knowledge. But it is precisely this knowledge that is precluded froin discovery by the near complete exemption for the CIA. Although the Agency's secrecy needs are compelling in some circuinstances, the balancing of those needs against the public's need for access is skewed by the virtual exclusion of public interests from the analysis. ${ }^{8}$ Because the exemption is nearly absolute, it has become impossible to verify the Agency's need for secrecy in individual cases; instead, extreme judicial deference to CIA conclusions of exemption has suppressed almost all data, whether or not its disclosure poses legitimate national security dangers.

In contrast, FOIA jurisprudence in the area of trade secrets and confidential coinmercial information obtained by governmental agencies permits much freer access than in the CIA/national security arena, although the popular need for the information is significantly less pressing im the commercial and financial context. The near-blanket exemption for the CIA distorts FOIA's underlying purpose, as does the co-opting of the Act's mechanism for access by businesses seeking coinpetitor trade secrets. Echoing Madison's sentiment above, Alexander Haimilton wrote that an informed electorate must "stand ready to sound the alarm when necessary, and to point out the actors in any permicious project." With this underlying philosophy, FOIA's mechanisn is clearly being abused by executives who use it as an industrial surveillance tool.

The financial and commercial information covered by FOIA Exemption 4-whether obtained by the government, by voluntary

8. Because of the sophistication of intelligence procedure, an appropriate assessment of the sensitivity of requested material may be beyond the limits of lay interpretation. Moreover, although the people "mean to be their own Governors," see supra text accompanying note 3, there is clearly a limit to the extent to which every citizen is permitted to review all governmental activities. The secrecy required by foreign intelligence is a very pressing need, quite apart from the popular source of the government's power. FOIA's design demands accommodation of these secrecy concerns as well as the public's need for access in its delicate balancing of interests. A blanket exemption for the CIA mherently distorts that balance.

9. THE FeDERALIST No. 84, at 266 (Alexander Hainilton) (Roy P. Fairfield ed., 3d ed. 1966). 
submission, or as part of a formal investigation-is not the stuff that comprises the heart of democratic self-rule. Information contamed withm these records ranges from scientific data about compliance with environmental regulations to corporate financial statements relating to securities issues. Whereas a requestor of CIA documents gets a peek into important matters of national security and foreign relations, the "public" in the trade secret context is viewing the internal operations of private industry, not the government. Thus, the different class of requestors in the Exemption 4 context signals an attenuation of the link between the information sought and the process of informing the electorate; it is a very specific public whose needs are being served. This attenuation is further manifested in the reasons that the information is held by the government in the FOIA Exeinption 4 context as compared with the CIA area. CIA documents are actually related to internal government activities, whereas the Exemption 4 information is private commercial information that happens to be contamed within governmental files.

The distinctly private nature of confidential commercial information must be considered in FOIA analysis. The information held by the CIA was created by the Agency itself as part of its role as an executive agency safeguarding national security, doubtless one of the central roles of government. ${ }^{10}$ Documents containing coinmercial and financial information are produced by businesses for their own purposes and shared voluntarily or otherwise with a regulatory agency. For example, when a major computer company is reviewed to determine its compliance with antitrust laws, the financial and commercial materials culled by the government in its investigation have hittle relevance to the process of deinocracy and an informed electorate; rather, they liave great pertinence to the interests of competitor corporations. The distinct purposes served by the two exeinptions compel a different balancing of interests. In the CIA context, the public need for access strongly supports disclosure of this important governmental information, yet tlie countervailing secrecy interests of the Agency deinand protection of the documents in cases of genume threats to national security. In the confidential commercial information context, the public need for access is lessened when the information does not shed light on

10. United States v. Curtiss-Wright Export Corp., 299 U.S. 304, 320-21 (1936). 
internal governmental processes and the privacy interests of the suppliers strongly support protection of the sensitive information. Despite this distinction, however, courts have failed to properly balance the competing interests. Trade secrets have been afforded considerably less protection by recent courts than CIA files, although the public need for the CIA information is far more pressing. Instead of the clear but conceptually misguided blanket exemption for the CIA, FOIA Exemption 4 law is a morass of tortured reasoning and unsettling results.

This Note addresses recent developinents in FOIA law at the circuit court level in both of these contexts, highlighting trends in the law as well as potential pitfalls. Throughout this survey, this Note evaluates the judiciary's success in achieving FOIA's precarious balance between the privacy needs of the government and its suppliers of information and the citizens' need for access. This Note concludes that the judiciary has perhaps inadvertently thwarted the purposes behind FOIA's enactment in attempting to achieve this balance in these areas. Part I of this Note analyzes three cases involving CIA claims of exemption from FOIA disclosure: Hunt v. $C I A,{ }^{11}$ Maynard v. $C I A{ }^{12}$ and Sullivan v. $C I A{ }^{13}$ It argues that the courts' reasoming im this area fails to fully consider FOIA's central purpose in its balancing of interests and acquiesces too quickly to the Agency's near-conclusive assertions of exemption. Part II discusses three decisions in which confidential commercial information is at issue in an Exemption 4 dispute: Critical Mass Energy Project v. Nuclear Regulatory Commission, ${ }^{14}$ A. Michaels Piano, Inc. v. FTC, ${ }^{15}$ and GC Micro Corp. v. Defense Logistics Agency. ${ }^{16}$ This Part argues that FOIA jurisprudence in the trade secrets area also misconceives the central purpose behind the Act by being too permissive of disclosure of private commercial information. Lastly, Part III offers suggestions to remedy these criticisms of the recent case rationales, proposing greater consideration of the fundamental purpose of FOIA in the careful balancing of interests demanded by these cases.

\footnotetext{
11. 981 F.2d 1116 (9th Cir. 1992).

12. 986 F.2d 547 (1st Cir. 1993).

13. 992 F.2d 1249 (1st Cir. 1993).

14. 975 F.2d 871 (D.C. Cir. 1992), cert. denied, 113 S. Ct. 1579 (1993).

15. 18 F.3d 138 (2d Cir.), cert. denied, 115 S. Ct. 574 (1994).

16. 33 F.3d 1109 (9th Cir. 1994).
} 


\section{The CIA AND National SeCURITY INFORMATION}

The courts' treatment of CIA claims of exemption from FOIA's disclosure mandate exemplifies the recent trend of departure from the fundamental purpose of FOIA in balancing the relative imterests and needs for the information. By failing to engage in meaningful judicial review and instead deferring almost completely to the Agency's conclusions, courts have been unable to effectuate FOIA's considered balancing of interests. In Part III, this Note suggests a new component to the existing judicial standards that would unify analysis of CIA cases with FOIA's principled design.

\section{A. Background of CIA Use and Abuse of FOIA Exemptions}

One of the areas in which the problems of recent FOIA jurisprudence are most prevalent is the treatment of proper access to the CIA's classified documents. Congress has acted in some ways to create new exemptions from disclosure for the CIA, ${ }^{17}$ but the FOIA framework still controls the analysis. Persons intending to use FOIA as a means of access to information held by the CIA face a unique set of procedures with which they must comply before disclosure is possible. Moreover, because of the extraordinary level of judicial deference to agency determinations in the CIA context, the Agency has numerous ways to avoid disclosing its information even after the procedural requirements are satisfied.

As with any FOIA request, a potential plaimtiff inust exhaust all administrative appeals of a demal of disclosure before appealing to a district court. ${ }^{18}$ Review by the district court is conducted de novo in CIA cases as well as all other FOIA disputes. ${ }^{19}$. As an imitial matter, the CIA determines whether it must disclose even the existence or non-existence of responsive documents. If the Agency determines that such an acknowledgment would itself jeopardize national security, then it may choose to issue a so-called Glomar response, a refusal to confirm or deny the existence or

17. See, eg., CIA Information Act, 50 U.S.C. \& 431 (1988); National Security Act, 50 U.S.C. \& 403(g) (1988) (establishing additional criteria that must be satisfied before disclosure will be mandated under FOIA and further buttressing the Agency's grounds for withholding the information).

18. 5 U.S.C. \& 704 (1988) (limiting judicial review generally to final agency actions); id. $\$ 552(\mathrm{a})(4)(\mathrm{B})$ (1988) (describing procedure for appeal to district court).

19. Id. \& 552(a)(4)(B) (1988). 
non-existence of the requested information. ${ }^{20}$ The requestor could then challenge the propriety of the Glomar response.

If the CIA determined that it could disclose the existence of records but refuse to share their substantive content, the district court proceeding would commence with the Agency's submission of Vaughn affidavits describing the requested records and explaining why the claimed exemptions apply. ${ }^{21}$ These affidavits inust set forth with reasonable precision the reasons for exemption as well as the specific statutory grounds for nondisclosure..$^{22}$ Under this sequence, nondisclosure is appropriate when the claimed exemption logically applies and the court determines that the Agency is acting in good faith in arguing for exemption from FOIA's mandates. $^{23}$ In Ray v. Turner, ${ }^{24}$ the court noted the distinctive aspects of de novo review in matters involving national security interests, including the substantial weight to be accorded to CIA affidavits regarding the classified status of the documents in question and the discretion of the court to conduct an in camera review of the disputed information. ${ }^{25}$

The ease with which courts weigh the competing interests of a FOIA requestor and the Agency and the near-uniformity of results uplolding the CIA's claim of exemption suggest that the application of this procedure by the courts has im recent cases become unsatisfactory. ${ }^{26}$ The procedural requirements are being used as a substitute for courts' judgments on the inerits, and tlie Agency rather than the judiciary is left wielding ultimate decisionmaking

20. Such an answer was first accepted by the court in Phillippi v. CIA, 546 F.2d 1009,1010 (D.C. Cir. 1976), in which the request concerned a ship called the Hughes Glomar Explorer.

21. The name for these affidavits is derived from Vaughn v. Rosen, 484 F.2d 820, 826-28 (D.C. Cir. 1973), cert. denied, 415 U.S. 977 (1974) (finding conclusory affidavits were insufficient and remanding to agency for unore specific justifications of claims to exemptions).

22. Allen v. CIA, 636 F.2d 1287, 1291 (D.C. Cir. 1980); Ray v. Turner, 587 F.2d 1187, 1191 (D.C. Cir. 1978).

23. Military Audit Project v. Casey, 656 F.2d 724, 738 (D.C. Cir. 1981).

24. 587 F.2d at 1187.

25. Id. at 1194.

26. For a concurrence that this trend is inappropriate, see Danae J. Aitchison, Comment, Reining in the Glomar Response: Reducing CIA Abuse of the Freedom of Information Act, 27 U.C. DAVIS L. REv. 219, 246-52 (1993) (arguing that Agency misuse of Glomar responses necessitates new FOIA amendments). See also Gregory G. Brooker, Note, FOIA Exemption 3 and the CIA: An Approach to End the Confusion and Controversy, 68 MINN. L. REv. 1231, 1260-61 (1984) (proposing an amendinent to FOIA that would force courts to be less deferential to CIA decisions). 
authority over the possibility of disclosure. Similarly, courts have been quick to defer to fairly broad agency justifications for withholding information, thus weakening the judiciary's ability to require the Agency to remain accountable to public scrutimy through FOIA. The most unsettling element of this trend is the piecemeal fashion by which this near-blanket exemption from disclosure has been created. The purpose of FOIA's access mechanisms has been slowly and subtly marginalized, and now without public notice, FOIA no longer applies in any meanimgful way to information lield by the CIA.

\section{B. Recent Developments Creating a Near-Blanket FOLA Exemp- tion for the CIA}

One of the more candid acknowledginents of this judicial failure to effectuate FOIA's fundamental purpose came in Hunt $v$. $C I A{ }^{27}$ The Hunt court upheld the CIA's refusal to confirm the existence of requested records while conceding that such a result not only creates a near-blanket exemption for the Agency but also may directly contravene congressional imtent. ${ }^{28}$ The plaintiff, who was then on trial for murder, made a FOIA request to the CIA for information regarding his alleged victim. The requested information mcluded records showing a relationship between the victim, an Iranian national, and the CIA; records detailing the victim's involvement with the U.S. Embassy and activities such as "efforts to effect a cliange im government in Iran after Khomeim came to power," drug trafficking, and blackmail; and copies of all correspondence and records of meetings involving the decedent. ${ }^{29}$ The CIA responded to this sweeping request by issuing a Glomar response, refusing to confirm or deny the existence of such records. $^{30}$ Specifically, the CIA cited the national security protections afforded by FOIA Exeniptions 1 and 3 as the statutory grounds for its refusal. ${ }^{31}$ The district court found for the request-

27. 981 F.2d 1116 (9th Cir. 1992).

28. Id. at 1120 .

29. Id. at 1117.

30. See supra note 20 and accompanying text.

31. Hunt, 981 F.2d at 1117. Although FOIA Exemption 1 specifically authorizes nondisclosure of records containing information relevant to national security, see supra note 5, many CIA context cases arise under Exemption 3, the general exemption including any additional nondisclosure authorized by statute. $I d$. 
or, concluding that withholding under Exemption 1 was improper when the agency's affidavits "failed to articulate a specific harm stemming from disclosure." 32 Moreover, the district court concluded that under the CIA Information Act, the CIA "can refuse to confirm or deny the existence of records only when the information would relate to covert actions." 33 The U.S. Court of Appeals for the Ninth Circuit, however, reversed and emphasized the CIA's virtually coinplete exemption from disclosure of information under FOIA. ${ }^{34}$

Sidestepping the Exemption 1 question, the court held that exemption froin disclosure was warranted under FOIA Exemption 3 and the National Security Act. ${ }^{35}$ The National Security Act confers responsibility on the CIA Director "for protecting intelligence sources and methods froin unauthorized disclosure. ${ }^{36}$ In addition, the CIA Information Act completely excludes most operational files from FOIA disclosure. ${ }^{37}$ The Hunt court echoed the Supreine Court's reasoning in $C I A v$. Sims, ${ }^{38}$ emphasizing in particular the broad scope of the CIA's ability to withhold information under Exemption 3. The fact that the court confined its analysis to examining the additional statutory bases for exemption from disclosure rather than addressing FOIA's exphicit exemption of national security information under Exemption 1 shows the degree to which the CIA is no longer a real participant in the FOIA scheme. Both judicial reluctance to adjudicate intelligence matters and congressional willingness to create numerous ways for the CIA to avoid disclosing its naterial have combined to effect a nearblanket exemption for the Agency. Furthermore, by interpreting the issue within the structure of Exemption 3, the catchall exemption that includes the additional, post-FOIA grounds for nondisclosure, the court shifts all responsibility for the CIA's exemption onto Congress. While congressional acquiescence in legislating additional CIA loopholes is responsible for inuch of the public's mability to access CIA information, the courts also are to blame when they opt to evade the tough questions posed by the statutory

\footnotetext{
32. Hunt, 981 F.2d at 1117-18.

33. Id. at 1118 .

34. Id. at 1120 .

35. Id. at 1118; 50 U.S.C. \& 403(d)(3) (1988).

36. 50 U.S.C. $\S 403(\mathrm{~d})(3)$.

37. Id. \& 431.

38. 471 U.S. 159 (1985).
} 
language im Exemption 1 and instead throw up their hands at what they claim to be Congress's work. When the balancing of interests is skewed by exclusion of the public's need for access from the analysis, the policy behind FOIA is ignored.

The Hunt court skewed the balance in this way by reasoning that, because the Agency keeps records on foreign nationals who are either CIA sources or targets as well as on foreign intelligence operatives, acknowledging existence or absence of such records could reveal or compromise sources and metliods. ${ }^{39}$ This reasoning would be acceptable if the court had engaged in substantive review of the Agency's determinations and had concluded that national security and intelligence interests genumely required withholding the information. Such substantive review would require greater factual specificity im affidavits and articulation of specific harm from disclosure, as well as involving more extensive scrutiny m in camera review. The reasoning hints at circularity, however, when the court allows the Agency's affidavits to prove themselves in conclusory language and suggests that all records are subsumed in an exemption for documents that reveal details of intelligence operations simply because the CIA is engaged in intelligence operations and keeps pertinent records. ${ }^{40}$ In defense of this assumed conclusion, the court explained that "the disclosure of the existence or non-existence of documents must not be viewed in isolation but rather as one tile in a mosaic of intelligence gathering."41 Thus, when looking at the wider pattern of intelligence operations froin which individual records are taken, "experts could then determine the contours and gaps of CIA intelligence operations and make informed judgments as to the identities of probable sources and targets." 42 Although this "pieces of the puzzle" danger may be compelling in certain cases, the Hunt court claimed judicial ignorance without engaging in meaningful review. It merely deferred to the CIA's uncontroverted assertions of danger and lack of judicial expertise to assess risk of disclosure. These claims by

39. Hunt v. CIA, 981 F.2d 1116, 1119 (9th Cir. 1992).

40. Id. The court permitted the Agency to assume its own conclusion: "According to CIA affidavits, barring a Glomar response, CIA intelligence gathering would be impaired by its own disclosures in response to FOIA requests." Id. Thus, the CIA argued from consequences without first proving with specific evidence that disclosure was mappropriate.

41. Id. at 1119.

42. Id. 
the Agency are impossible to refute because the underlying information is solely within the CIA's control and clearly beyond the court's desire to adjudicate.

Beyond simply the danger of revealing information, however, the Ninth Circuit offered additional rationales for withholding such information. From a CIA policy perspective, disclosure of such information regarding sources and inethods of intelligence could have more subtle and far-reaching consequences. The court accepted the Agency's position that, after disclosure, "potential future sources would be reluctant to come forward; targets of intelligence scrutiny would be alerted and could take additional precautions; and foreign operatives could learn whether or not the CIA was aware of their activities." ${ }^{43}$ Because the court concluded that "disclosure of the existence or non-existence of records pertaining to [the victim] is tantamount to a disclosure whether or not he was a CIA source or intelligence target," ${ }^{, 44}$ the court did not require the Agency to make an additional showing of a "high degree of damage to CIA intelligence gathering." 45 Thus, the court acquiesced to the CIA's insistence that "any such interest, if made public, may create the danger that sources and metlods of intelligence gathering will be compromised." 46 This scintilla of danger rule obviates the need for proof in individual cases of heightened risk inherent in disclosure.

Significantly, the Hunt court not only exempted the Agency from complying with the FOIA request but also permitted the Agency to avoid giving a concrete answer as to the existence of responsive documents. Thus, the court held that "tlie CIA's affidavits explam the Agency's conclusion that a Glomar response is required to protect imtelligence sources and inethods. In light of the Director's extensive power to protect these sources and inethods, we conclude that Hunt's request is exempt from FOIA." The court then acknowledged the far-reaching ramifications of its holding in terms of the CIA's relation to the FOIA doctrime and structure. The court explained that "with this decision, we are now 'only a short step [from] exempting all CIA records' from
43. Id.
44. Id.
45. Id. at 1120 .
46. Id.
47. Id. 
FOIA." ${ }^{48}$ The court recognized the profound disjuncture between this virtually per se exemption and the spirit of FOIA: "That result may well be contrary to what Congress intended." 49 This concession is an extraordmary comment on the current state of FOIA jurisprudence and also demonstrates the departure by the court from the fundamental purpose of the Act. After such an admission that the result may directly controvert Congress's design for FOIA, it is unclear how the court could believe that it was nonetheless justified in its conclusion. Citing a now-anachromistic statement in legislative history, the court posited what was once touted to be the success of FOIA as the breakdown im current FOIA jurisprudence. The court quoted a 1984 congressional report statimg "that FOIA 'has played a vital part in maintaining the American people's faith in their government, and particularly in agencies like the CIA." "50 Further stressing the irony of this assertion, the court explained that "[w]hether or not that was actually the case at one time, it certainly is not true now, at least insofar as the CIA is concerned." 51

According to the Hunt court, the only available recourse to this evolution of CIA-FOIA jurisprudence is congressional action: "If Congress did not intend to give the CIA a near-blanket FOIA exemption, it can take notice of the court's imcremental creation of one, and take the necessary legislative action to rectify the matter." ${ }^{, 52}$ Here the court recognized that not only is it being extreinely permissive of the Agency's determinations but also such permissiveness directly contravenes congressional intent. By responding to this inconsistency with FOIA's central purpose witl a suggestion that it is Congress's obligation to return FOIA jurisprudence to its textual limits, the court is completely abdicating its proper judicial role.

After Hunt, other courts articulated similar reasoning in their refusal to compel the CIA to produce documents over its objections. In Maynard v. CIA, ${ }^{53}$ the First Circuit upheld the CIA's

48. Id.

49. Id.

50. Id. (quoting H.R. REP. No. 726, 98th Cong., 2d Sess. 9 (1984), reprinted in 1984 U.S.C.C.A.N. 3741, 3747).

51. Id.

52. Id.

53. 986 F.2d 547 (1st Cir. 1993). 
claims for exemption of the requested information, ${ }^{54}$ emphasizing its reluctance to question the Agency's own conclusions and to engage $\mathrm{m}$ rigorous balancing of the interests. ${ }^{55}$ In Maynard, the FOIA requestor was the former wife of a man who disappeared on a flight over Cuba im 1961 while allegedly distributing antiCastro leaflets. The CIA invoked FOIA Exemptions 1 and 3 as its basis for refusing the request. ${ }^{56}$ The district court rejected the agency affidavits, stating instead that the "assertion that disclosure will 'reveal its sources and methods' in a matter now approximately thirty years old is without substance and is, indeed, the height of bureaucratic disingenuousness." ${ }^{\text {}} 7$ On appeal, the circuit court reversed, holding that the information was exempt from disclosure because "it is at very least 'arguable' that the requested paragraph falls within [the National Security Act] for the reason the CIA gave, to wit, that it could reveal intelhgence methods." 58

In its opinion, however, the court did little to elucidate the reasons why such an unsupported assertion was acceptable. More importantly, the opinion failed to address the district court's arguments raised in its attack on the Agency for continually stonewalling attempts by citizens to gain access to its information. The court simply deferred to the Agency's affidavits, explaining that "judges 'have hittle or no background in the dehcate business of imtelligence gathering' and may be unable to comprehend the significance of material that appears to be innocuous, but in fact can reveal a significant intelligence source or method." ${ }^{, 59}$ Allowing the Agency's affidavits to bootstrap themselves imto exemption and to prove their own arguments highlights the dilemma at the heart of CIA-FOIA jurisprudence. Because the Agency has total authority over the documents in question and because non-agency reviewers cannot and will not properly assess the potential problems caused by disclosure, the courts are forced to acquiesce to the CIA position. The extreme deference demonstrated by the court is tantamount to sanctioning the Agency's own conclusion in every case; the authors of FOIA certainly had a more meaningful mechanism of review in mind when they designed a franiework mclud-

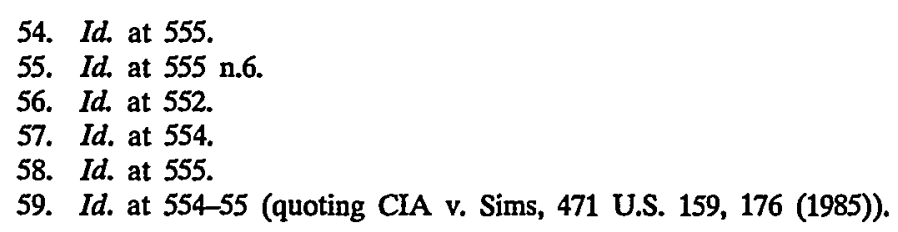


ing de novo review. This difficulty is exemplified by the Maynard court's rejection of the district court's finding that the advanced age of the information supported its disclosure. On appeal, the court stressed its reluctance to articulate a time-specific rule because "it is virtually impossible for an outsider to ascertain what effect the passage of time may or may not have had to mitigate the harm froin disclosure of sources and inethods." ${ }^{100}$ Indeed, the court posited a broader view of the time period significant to intelligence operations, looking at thirty years not as a long time but rather as "well within the careers of hiving persons including government leaders (like Cuba's leader) still in power." ${ }^{.61}$ Rather than addressing the difficult task of balancing the relative interests, the court simply deferred to the Agency's determinations: "The CIA, not the judiciary, is better able to weigh the risks that disclosure of such information may reveal intelligence sources and methods so as to endanger national security."62

Although concluding that its analysis under Exemption 3 resolved the issue, the Maynard court also discussed the CIA's argument for nondisclosure under Exemption $1 .^{63}$ The court stressed the high level of deference accorded to the Agency's affidavits as long as the searches were adequately performed and there was no evidence of bad faith by the CIA. ${ }^{64}$ Because the information "'arguably' or 'logically' pertamed to intelligence methods," it could be withheld under FOIA Exemption $1 .^{65}$ The court emphasized its unease in reviewing the matter: "We are not in a position to 'second-guess' the CIA's conclusion regarding the need for continued classification of this material."

60. Id. at 555 n.6.

61. Id.

62. Id.

63. Id. at 555-56. For a discussion of the procedures required in CIA cases arising under FOIA, see supra notes 18-25 and accompanying text. The distimction between analysis nnder Exemptions 1 and 3 is as follows: under Exemption 1, the Agency must show that it is protecting records " $m$ the interest of national defense or foreign policy"; Exemption 3 allows additional enabling statutes to confer broader discretion on the Agency and to sanction nondisclosure. See, e.g., 50 U.S.C. \& 403(d)(3) (1988) (authorizing the CIA director to protect "intelligence sources and methods"); see also supra text accoinpanying notes $31-38$.

64. Maynard, 986 F.2d at 555-56.

65. Id. at 556.

66. Id. at 556 n.9. 
Significantly, the Maynard court concluded that there was no public interest in access to the material in question. In the absence of any public need for access, therefore, the secrecy interests of the Agency supported nondisclosure. ${ }^{67}$ In support of its reasoning, the court cited the Supreme Court in Department of Justice $v$. Reporters' Committee for Freedom of the Press, stating that "the only cognizable 'public interest' for purposes of FOIA is 'the citizens' right to be informed about 'what their government is up to." "68 According to the Maynard court, when the information souglit is purely about private citizens and not more generally illustrative of governmental actions and procedures, " $[t]$ hat purpose . . . is not fostered by disclosure of information about private citizens that is accumulated in various governmental files but that reveals little or nothing about an agency's own conduct." ${ }^{69} \mathrm{By}$ defining the popular right to knowledge narrowly, the Maynard court was able to conclude that interaction between a government agency and an individual citizen lies beyond the scope of the needs of an informed electorate. Thus, the balancing of interests was again skewed against accommodation of public need for access and in favor of a near-blanket exeinption for the CIA.

Later in 1993, the First Circuit revisited the FOIA issue in circumstances also involving CIA anti-Castro operations. Once again it acquiesced to the Agency's insistence on nondisclosure by deinanding a high degree of specificity in the FOIA request. In Sullivan v. $C I A,{ }^{70}$ the court upheld the Agency's reliance on the CIA Information Act of $1984^{71}$ and rejected a FOIA request inade by the daughter of a man who disappeared while allegedly participating "in a CIA-sponsored mission to drop propaganda (or perliaps something more sinister) over Cuba."72 In discussing the history and structure of FOIA, the court einpliasized the cost-benefit problems inherent in a CIA response to a FOIA request and the difficulty experienced by outsiders in accurately assessing the risk associated witl disclosure of intelligence data. The court referred to "the arcane realm of the CIA," suggesting its discoinfort

67. Id. at 566 (citing FLRA v. Dep't of Navy, 941 F.2d 49, 57 (1st Cir. 1991).

68. Id. (quoting Department of Justice v. Reporters' Comm. for Freedoin of the Press, 489 U.S. 749, 773 (1989)).

69. Id.

70. 992 F.2d 1249 (1st Cir. 1993).

71. 50 U.S.C. \& 431 (1988).

72. Sullivan, 992 F.2d at 1251. 
at passing judgment in an area of such little judicial or other accessible expertise. ${ }^{73}$

The Sullivan court began its analysis with a subtle criticisin of the broad exemptions existing within FOIA, hinting at the benefits of a blanket CIA exeinption from the Act. The court explained:

FOIA does not give the CIA carte blanche to refrain from producing docuinents merely because it is an intelligence agency. Consequently, the CIA had to divert trained intelligence officers to search its entire file system in response to FOIA requests, notwithstanding the relatively limited number of non-exempt documents likely to be culled. ${ }^{74}$

In light of these "inefficiencies," the court explained that Congress had enacted the CIA Information Act to create additional FOIA exeinptions. ${ }^{75}$ The effect of the CIA Information Act was to eliminate the need for the Agency to search its operational files in most instances. Again, however, Congress provided a mechanisin for the disclosure of "highly informative" information by creating certain exceptions within the CIA Information Act. ${ }^{76}$ These exceptions imcluded disclosure of "first-party requests, special activity requests, and requests that focus on investigations of improprieties

73. Id. at 1256.

74. Id.

75. Id. The CIA Information Act, 50 U.S.C. $\S 431$ (1988), provides in relevant part:

(a) Operational files of the Central Intelligence Agency may be exempted by the Director of Central Intelligence from the provisions of section 552 of title 5 (Freedom of Information Act) which require publication or disclosure, or search or review in connection therewith.

....

(f) Whenever any person who has requested agency records under section 552 of title 5 (Freedom of Information Act), alleges that the Central Intelligence Agency has improperly withheld records because of failure to comply with any provision of this section, judicial review shall be available under the terms set forth in section 552(a)(4)(B) of title 5, except that-...

(4)(A) when a complainant alleges that requested records were improperly withheld because of improper exemption of operational files, the Central Intelligence Agency shall meet its burden under section 552(a)(4)(B) of title 5 by demonstrating to the court by sworn written submission that exempted operational files likely to contain responsive records currently perform the functions set forth in subsection (b) of this section [the definition of operational files]; and

(B) the court may not order the Central Intelligence Agency to review the content of any exempted operational file or files in order to make the demonstration required under subparagraph (A) of this paragraph, unless the complainant disputes the Central Intelligence Agency's showing with a sworn written submission based on personal knowledge or otherwise admissible evidence.

76. Sullivan, 992 F.2d at 1251. 
in intelligence-gathering activities." 77 The Sullivan court construed these exceptions strictly, concluding that nondisclosure was appropriate under the circumstances. ${ }^{78}$

In its analysis, the court emphasized two basic concerns underpinning the CIA's claim for exemption: specificity and secrecy. ${ }^{79}$ In order to satisfy the specificity concern of the special activity exception, the burden is on the FOIA requestor to "identify a particular CIA activity in connection with his or her request." ${ }^{180}$ The court cited legislative history as support for its construction of the term "special activity" as "any activity of the United States Governinent, other than an activity intended solely for obtaining necessary intelligence, which is planned and executed so that the role of the United States is not apparent or acknowledged publicly." ${ }^{\prime 1}$ This definition as apphed to FOIA requests is paradoxical because it requires such specificity from a FOIA requestor who wants information about an operation that is by definition secret.

As guidelines for its specificity requirement, the First Circuit listed both sufficiently and insufficiently specific examples of requests that appeared in legislative history and caselaw and conrpared them with the Sullivan circumstances. In these examples, according to the court, requests relating to the Bay of Pigs invasion or the coup d'etat in Guaternala in the 1950s would meet the requisite threshold of specificity, whereas a request for information regardmg the existence of covert efforts to counter Soviet intelligence in Western Europe during the 1950s would not be sufficiently precise. $^{82}$ In light of these examples, the court concluded that the Sullivan request was "too expansively described to slip within the integument of" the "special activity" exception. ${ }^{83}$ The court's justification for this conclusion included the length of time of the CIA's campaign agamst Castro, the breadth of the operations, and the numerous parties involved. ${ }^{84}$ Because of the sweeping impact

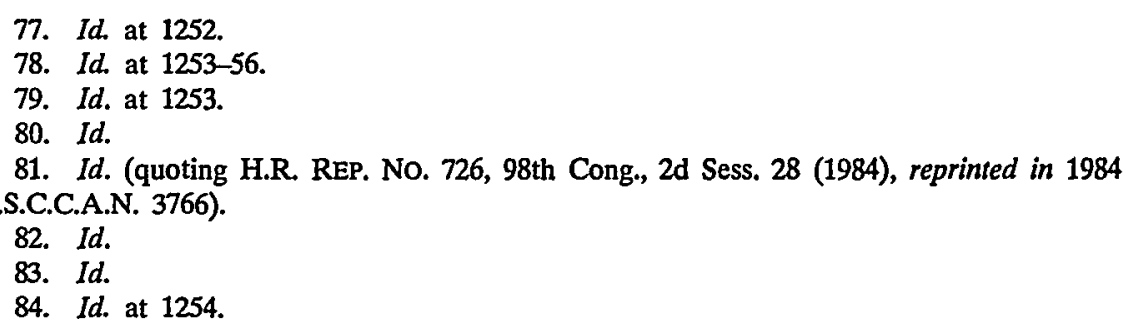


of CIA involvement in an anti-Castro movement, the court held that the request was not detailed enough im its demands.

If the court had viewed the request in hight of FOIA's overriding purpose and adequately accounted for the public interests, it seems difficult to imagine a case in which information would be more important to the public and to a requestor whose next of kin may have died in the efforts. The very reasons that the court gave in support of its conclusion undercut its analysis; it is precisely because of the enormous lengtli and scope of the Agency's involvement in an anti-Castro campaign that the information is so relevant. Moreover, there is no elucidation in the court's opinion or in the arguinents acknowledged of the present danger of releasing such information. Indeed, such vastly important information to the American public gains even more interest if its value is historical in nature and if disclosure will not prejudice any current operations.

After discussing the lack of specificity in the Sullivan request, the court concluded that the demand for information also failed under the secrecy aspect of the "special activity" exception. ${ }^{85}$ The court explained that although the CIA lad acknowledged involvement in an operation and even responded to congressional investigations regarding the incidents, the FOIA requestor in this case did not inerit access to the underlying information. ${ }^{86}$ While the court's arguments that the request was simply too renıte in relation to the investigations are sustainable, the court failed to recognize potential problens with its analysis. When the Agency admits its involvement and when legislative action has been taken to inquire into a matter, to allow the CIA to retain complete control over the information at issue is to remove it from the scope of FOIA in its entirety. The Agency retains all the power in this situation, and by keeping the documents classified with the courts' acquiescence and imphed approval, the FOIA requestor is doomed to fail. Even with congressional action to support an inquiry, the individual requestor cannot succeed. Without more information, the request cannot be inade inore specific without Agency cooperation, and the information can stay secret nearly indefinitely.

Echoing the Hunt and Maynard courts' abdication of judicial responsibility, the court emphasized that "Congress crafted the 
CIA Information Act to strike a balance between public disclosure and an effective intelligence apparatus. Our role is not to reassess the relative interests ... or to yield whenever human sympathies are engaged, but simply to apply the law as Congress wrote it." Though Congress may indeed share in the blame for the failure of FOIA to strike a workable balance, the courts in Hunt, Maynard, and Sullivan are equally responsible for the near complete exemption of intelligence inaterials from FOIA's calculus to achieve public access to governmental inaterials. By failing to engage in a ineaningful review of the substantive claims, the courts neglected to adequately consider both countervailing interests in the balance.

\section{EXEMPTION 4: CONFIDENTIAL COMMERCIAL INFORMATION}

In assessing the propriety of FOIA disclosure of confidential commercial information, courts have failed to consider the guiding purpose of the Act in their analysis. Without questioning the apphicability of the fundaniental purposes of FOIA to a particular situation, courts cannot adequately strike a balance between the public's need for access to governmental information and the supphers' needs for privacy. In Part III, this Note suggests factors to be considered in a more ineaningful judicial review of this delicate balance.

\section{A. Background of the Use and Abuse of FOIA Exemption 4}

FOIA's Exeinption 4 permits refusing a request for trade secrets or private, confidential information of a commercial or financial nature that is held by the government. ${ }^{88}$ The records at issue under this exenption are conceptually distinct froin those of the CIA discussed above as they are prepared by private individuals or organizations in the course of business and are being held by the government for various administrative purposes. Thus, such information is not itself reflective of governmental processes, but instead may be highly illuminative of a corporation's internal financial structure and commercial viability. The courts have been sensitive to the distinctive nature of this information and have attempted to craft modes of analysis that protect the confidentiality of the information. ${ }^{89}$

87. Id. at 1256.

88. 5 U.S.C. § 552(b)(4) (1988); see supra note 5.

89. See, e.g., National Parks \& Constr. Ass'n v. Morton, 498 F.2d 765, 770 (D.C. Cir. 
Specifically, courts have distinguished between information voluntarily submitted to the government and documents obtained by subpoena or other involuntary means. ${ }^{90}$ Voluntarily submitted information provides the least amount of insight into governmental activities because unlike subpoenaed information it is not usually obtained within the course of an active government iuvestigation. Thus, voluntarily submitted information is the least probative in the citizens' quest to inform themselves about governmental affairs. This mode of analysis was articulated in the National Parks test, which defined as confidential and exempt under Exemption 4 any commercial or financial information that, if disclosed, would be likely "(1) to impair the Government's ability to obtain necessary information in the future; or (2) to cause substantial harm to the competitive position of the person from whom the information was obtained." ${ }^{\prime 11}$ This test continues to guide Exemption 4 analysis today, although the results it produces are occasionally schizophrenic and often contravene of the purposes behind FOIA's enactment and design.

\section{B. Recent Developments Creating a Conflicting and Unprincipled Exemption 4 Jurisprudence}

Whereas the courts have been too lenient in their acquiescence to CIA objections to compelled FOIA disclosure, Exemption 4 analysis involving confidential commercial or financial information has produced more varied results under highly conflicting rationales. In late 1992, the D.C. Circuit attempted to clarify the test appropriate for Exeinption 4 FOIA cases. In Critical Mass Energy Project v. Nuclear Regulatory Commission, ${ }^{92}$ the D.C. Circuit, sitting en banc, protected private commercial information from disclosure under FOIA ${ }^{93}$ and, in so doing, further complicated Exemption 4 jurisprudence. The court reconsidered the long-

1974), discussed infra text accompanying note 91; Critical Mass Energy Project v. Nuclear Regulatory Comm'n, 975 F.2d 871, 880 (D.C. Cir. 1992) (Critical Mass III), discussed infra text accompanying notes 92-120; A. Michael's Piano v. FTC, 18 F.3d 138 (2d Cir), cert. denied, 115 S. Ct. 1579 (1994), discussed infra text accompanying notes 121-44.

90. See National Parks, 498 F.2d at 765, discussed infra text accompanying note 91.

91. National Parks, 498 F.2d at 770 (citations omitted).

92. 975 F.2d 871 (D.C. Cir. 1992) (en banc). As discussed infra note 102 and accompanying text, the present decision is actually the third holding in a series of conflicting results; thus, this case is properly referred to as Critical Mass III.

93. Id. at $\mathbf{8 8 0 .}$ 
standing National Parks ${ }^{94}$ test and concluded that the test was still vahid as apphed to information provided to the government involuntarily. The court then articulated a new test for voluntarily submitted data, treating it as confidential for Exemption 4 purposes "if it is of a kind that the provider would not customarily make available to the public." 95

The court articulated two interests that are at stake in Exemption 4 cases. First, the government has an interest in ensuring the continued availability of confidential cominercial information so that administrative agencies may conduct reviews in a substantive manner. Second, the private individual or corporation has an interest in protecting the privacy of its information and the continued viability of its economic position from FOIA-sanctioned industrial espionage. ${ }^{96}$ Thus, the voluntariness of the submission of the information to the government is essential to an analysis under Exemption 4 that is in harmony with FOIA's overall framework and purpose. In National Parks, the information was provided under compulsion, and the court's holding in that case was based specifically on the fact that there was no danger that public disclosure would harm the government's ability to obtain similar inforination in the future. ${ }^{97}$

The court in Critical Mass III, however, distinguished between mandatory submission of mformation in National Parks and the voluntary submission at issue here. ${ }^{98}$ In Critical Mass III, the requested information included safety reports regarding the construction and operation of nuclear power plants and facilities compiled by the Institute for Nuclear Power Operations, whose members include management of all American nuclear power plants. ${ }^{99}$ The reports were inade available voluntarily to the Nuclear Regulatory Commission (NRC) on the "exphicit understanding that they are not to be disclosed to additional persons without [the Institute's] consent." ${ }^{100}$ Voluntarmess pervaded the data collection and distribution process. The Institute was a nonprofit organization formed

94. See supra text accompanying note 91 .

95. Critical Mass III, 975 F.2d at 872.

96. Id. at 873 (quotimg National Parks \& Constr. Ass'n v. Morton, 498 F.2d 765, 770

(D.C. Cir. 1974)).

97. National Parks, 498 F.2d at 770.

98. Critical Mass III, 975 F.2d at 878.

99. Id. at 874 .

100. Id. 
after the 1979 Three-Mile Island nuclear accident for the purpose of promoting safety and rehiability in the nuclear power plant industry. While it was not itself subject to regulation by the NRC, its members were, and the NRC received the reports in the absence of any duty by the Institute.

The public interest motivation behind the formation of the Institute and its continued work was significant. Because of the 1979 accident, a nonprofit group was formed to act as a semi-external check on the operations of power plants. ${ }^{101}$ Thus, the lofty democratic ideals cited as the basis for FOIA's existence were acted upon in a private mode im the creation of the Institute; the Institute was the nongovernmental vehicle by which the industry executives performed a quasi-executive role in keeping watch over the health and safety of citizens. Thus, motivations similar to those behind FOIA's passage underpimied the Institute's work to the extent that it was formed voluntarily to protect Americans from collusive and potentially dangerous behavior by industry, rather than by government. While the NRC's aegis is limited to investigations and a more policing function, the Institute exists for the purpose of full and voluntary disclosure of information withm the industry and the government.

After a series of conflicting decisions and two earlier panel decisions, ${ }^{102}$ the D.C. Circuit elected to rehear the case en banc. In Critical Mass III, the D.C. Circuit affirmed the National Parks test in the interest of stare decisis but limited its applicability to cases in which the information was compelled by the government. ${ }^{103}$ The court explained the distinction between voluntarily submitted and compelled information under each of the two interests-governmental and private-underpinning Exemption 4 analy-

101. Id.

102. Critical Mass Energy Project v. Nuclear Regulatory Comm'n, 644 F. Supp. 344 (D.D.C. 1986); Critical Mass Energy Project v. Nuclear Regulatory Comm'n, 830 F.2d 278 (D.C. Cir. 1987) (Critical Mass I); Critical Mass Energy Project v. Nuclear Regulatory Comm'n, 731 F. Supp. 554 (D.D.C. 1990); Critical Mass Energy Project v. Nuclear Regulatory Comm'n, 931 F.2d 939 (D.C. Cir. 1991) (Critical Mass In). The procedural background is significant not only in understanding the opinion at hand, but more importantly as a vivid indication of the jurisprudential morass that Exemption 4 analysis has become. The sequence of holdings and rationales is also illustrative of the intense difficulty the courts have had in formulating a workable definition of "confidential" for the purposes of Exemption 4 construction. In particular, it highlights the pressing need for clarity in this area, where so much is at stake and so little is predictable.

103. Critical Mass III, 975 F.2d at 880. 
sis. As to the governmental interest when information is compelled, the inquiry focuses primarily on the effect public disclosure has on the quality of the information. ${ }^{104}$ Regarding voluntarily submitted information, however, the main concern of the government is safeguarding the cooperative relationship between the supplying business entity and the government. ${ }^{105}$ According to the Critical Mass III court, the same distmction between policy objectives in support of withholding the information exists with respect to the private interest against commercial disadvantage. The innovation of Critical Mass III was the recogmition of "a private interest in preserving the confidentiahty of information that is provided to the Government on a voluntary basis," in addition to the traditional acknowledgment of governmental interests in adinimistrative efficiency and effectiveness. ${ }^{106}$ Thus, the court incorporated additional bases for maintaiming confidentiahty while leaving open the question of whether even more interests might also support the exemption of confidential commercial information from FOIA disclosure. ${ }^{107}$

The court then applied the newly expanded Exemption 4 analysis to voluntarily submitted information and concluded that "financial or commercial information provided to the Government on a voluntary basis is 'confidential' for the purpose of Exemption 4 if it is of a kind that would customarily not be released to the public by the person from whom it was obtamed." ${ }^{108}$ In support of this conclusion and the establishment of this additional criterion, the court referred to the "matter of common sense" dictating that "the disclosure of information the Government has secured from voluntary sources on a confidential basis will both jeopardize its continuing ability to secure such data on a cooperative basis and injure the provider's interest in preventing its unauthorized release." 109 In the final understanding, then, the court held that

104. Id. at 878.

105. The court concluded succinctly, "Thus, when information is obtained under duress, the Government's interest is in ensuring its continued reliability; when that information is volunteered, the Government's interest is in ensuring its continued availability." $I d$.

106. Id. at 879. The governmental interests in efficiency and efficacy, noted in the now-overruled Critical Mass I opinion, 830 F.2d 278 (D.C. Cir. 1987), were derived by the First Circuit in 9 to 5 Org. for Women Office Workers v. Bd. of Governors, 721 F.2d 1, 11 (1st Cir. 1983).

107. Critical Mass III, 975 F.2d at 879.

108. Id.

109. Id. 
this further complication of Exemption 4 jurisprudence was justified both by sophisticated statutory intent arguments and by common sense.

Applying this analysis to the Critical Mass III facts, the court held that information contained withm the reports was voluntarily provided commercial information that was not usually released to the public by the Institute. Thus, the data was confidential under Exemption 4 and thereby protected from public disclosure under FOIA. ${ }^{110}$ One of the most troubling consequences of this analysis, however, is the inference suggested by Critical Mass Energy Project in its argument that government and industry may be encouraged "to conspire to keep information from the public by agreeing to the voluntary submission of information that the agency has the power to compel."111 Deeper, however, is the concern that the understanding of confidentiahity is really a contracting away of disclosure obhigations. The Critical Mass III court's response to these suggestions was simply to emphasize that there is no FOİA requirement "that obhiges agencies to exercise their regulatory authority in a manner that will maximize the amount of information that will be made available to the public" and that the NRC's discretion regarding modes of obtaiming data was beyond the court's power to second-guess. ${ }^{112}$

The analysis of the court, while ostensibly founded in statutory language and intent as well as common sense, was not accepted by all members of the en banc panel. Judge Randolpli, joined by Judges Silberman and Sentelle, concurred in the opinion of the court somewhat reluctantly, conceding that stare decisis counseled against flatly overruling National Parks while msisting that proper analysis of Exemption 4 focused primarily on the language of the Act itself and not additional judicial criteria. ${ }^{113}$ Four otler members of the Circuit, however, dissented from the supposedly clari-

110. Id. at 880 .

111. Id.

112. Id.

113. Id. at 882 (Randolph, J., concurring). It is, of course, paradoxical that Judge Randolph's attack on the National Parks test in his Critical Mass II concurrence, 931 F.2d 939, 947 (D.C. Cir. 1991) (Randolph, J., concurring), charged that the test was an unfounded additional criterion demanded of Exemption 4 analysis, while he apparently accepted the articulation of a distinction between voluntarily submitted and compelled information in Critical Mass III, a distinction found nowhere in the language of the exemption itself. 
fied opinion in Critical Mass III. In dissent, Judge Ginsburg, joined by Chief Judge Mikva and Judges Wald and Edwards, argued that the principle of stare decisis required full affirmance of the National Parks test and that "the guiding purpose of [FOIA]-to shed light on an agency's performance of its statutory duties"-was not uplield by the majority's reasoning. ${ }^{114}$

The dissent cliallenged the objectivity of the majority's new test, noting that witlout "an independent judicial check on the reasonableness of the provider's custoin [against public disclosure] and the consonance of that custom with the purposes of exeniption 4," the court simply acquiesced to allowing providers "to render categories of information confidential merely by withholding them from the public long enough to show a custoni." is subjective to the degree that it wrests control from the public and the judiciary and places it within the total control of the business entity providing the information. The dissent assailed the majority's test for its dislıarnony witl "Congress' unmistakably clear direction: 'The mandate of the FOIA calls for broad disclosure of Government records." "116 By dispensing witl the requirement of slowing how disclosure affects private or governmental interest as defined by National Parks, the dissent insisted that Exemption 4 will balloon far beyond congressional intent. Without a thoughtful balancing of the relative interest, courts will give in to "the temptation of government and busmess officials to follow the path of least resistance and say 'confidential' whenever they seek to satisfy the government's vast information needs."117

The dissent also argued against the use of a categorical approach to FOIA analysis without examining the character of the underlying data. Looking to the facts of Critical Mass, the dissent insisted that "disclosure is souglit 'not primarily im the commercial imterest of the requestor,' but to advance public understanding of the nature and quality of the NRC's oversiglit operations or activities." The problem with this argument lies in its blimdness to otler uses of the information, uses which could be commercially

114. Critical Mass III, 975 F.2d at 882 (Ginsburg, J., dissenting).

115. Id. at 883.

116. Id. at 884 (quoting CIA v. Sims, 471 U.S. 159, 166 (1985)).

117. Id. at 885 (quoting 9 to $5 \mathrm{Org}$. for Wounen Office Workers v. Bd. of Governors, 721 F.2d 1, 12 n.5 (1st Cir. 1983) (Breyer, J., dissenting)).

118. Id. (quoting Department of Justice v. Reporters' Comm. for Freedom of the Press, 489 U.S. 774, 775 (1988)). 
disastrous to the businesses supplying the information. While the FOIA requestor in this particular case was a consumer advocacy group, there was certainly no restriction of access to nonprofit groups or non-competitors of the information suppher. Moreover, there is no restriction on the use of the information by the FOIA requestor once it is received. Thus, whereas this case presents a FOIA requestor with a publicly beneficial purpose, there is no objective analytical distinction between this case and the FOIA requestor in another case who might want tlie information for ler own commercial needs. ${ }^{119}$ Nonetheless, the dissent eclioed its earher call for a sincere assessment of the interests, insisting that the majority's holding was tantainount to "the virtual abandonment of federal court scrutiny" of voluntarily submitted commercial or financial materials. ${ }^{120}$

The issue of disclosure of confidential commercial information was rendered even unore complex by the Second Circuit in $A$. Michael's Piano, Inc. v. FTC. ${ }^{121}$ The court in A. Michael's Piano added yet another case-specific test to the Exemption 4 tlicket. It demanded consideration of whetler the information was collected as part of an investigation and whetler the agency liad the power to subpoena the records if not voluntarily submitted. ${ }^{122}$ After chastising the district court for erring too far on the side of nondisclosure, the court then proposed yet another test to determine when commercial information obtained by the government must be shared with private citizens. ${ }^{123}$ The FOIA requestor in this case was a former retail distributor of Steinway pianos wlio wanted access to corporate records that Steinway had voluntarily submitted to the Federal Trade Commission (FTC) on the mutual understanding that they would not be made public. The court acknowledged tlie strong political rlietoric underpinning FOIA disclosure, citing as the statute's premise

the Founders' view that "the people are the only legitinate fountaim of power, and it is from them that the constitutional charter, under which the several branches of government hold their pow-

119. See, e.g., A. Michael's Piano, Inc. v. FTC, 18 F.3d 138 (2d Cir.), cert. denied, 115

S. Ct. 1579 (1994); see infra text accompanying notes 121-44.

120. Critical Mass III, 975 F.2d at 886 (Ginsburg, J., dissenting).

121. $18 \mathrm{~F} .3 \mathrm{~d}$ at 138 .

122. Id. at $145-46$.

123. Id. at 146; see infra text accompanying note 143. 
er, is derived".... [O]ur government, relying as it does on the consent of the governed, may not succeed unless its "people who mean to be their own governors... arm themselves with the power knowledge gives." 124

The court attempted to balance this interest against the recognition that "if every document in the possession of a federal agency was freely available to the press or public, not many documents would be voluntarily submitted." 125

The records at issue involved Stemway's manufacturing processes and warranty practices. The FTC had investigated allegations that the manufacturer "had failed to honor warranties, particularly those with respect to cracks or other asserted flaws in the soundboards of its pianos." 126 As part of the inquiry, the FTC collected documents froin Steinway as well as at from least six of its competitor corporations. The information requested by the FTC included "a broad range of documents and information concerning the manufacturer, its dealers, manufacturing processes, and warranty practices." 127 The data was obtained from Steinway "voluntarily ... [i]n furtherance of [the pending] investigation" and with the understanding that such data "provided voluntarily in heu of compulsory process in a law enforcement imvestigation ... [is] exempt from public disclosure under [FOIA Exemption 3]." 128 Thus, the definition of "voluntary" suggested by this investigation includes an element of implied threat, as the FTC investigation already had commenced and compulsory production of information could be demanded by the agency.

Steinway produced voluntarily "a substantial amount" of information, and the FTC collected information from "a number of retail piano dealers, technicians, and owners." ${ }^{\prime 29}$ All letters and documents collected by the agency as part of its investigation of Steinway were sought by the FOIA requestor. Significantly, A. Michael's Piano had a soinewhat strained relationship with Steinway after it refused a new dealership contract written by Steinway that would have pressured the dealer to adhere to the manufactur-

\footnotetext{
124. Id. at 140 (citations omitted).

125. Id. at 141 .

126. Id.

127. Id. at 142 .

128. Id. (quoting 15 U.S.C. $\& 57 \mathrm{~b}-2(\mathrm{f})(1988)$ ).

129. Id.
} 
er's suggested retail prices for the pianos. ${ }^{130}$ After the new contract was rejected, no new Steinway pianos were shipped to the dealer, which had been the largest single-location Steinway dealer in the country. ${ }^{131}$

Thus, it is against this background that A. Michael's Piano naade its request for information. The FTC denied the request, citing Exenuptions 3 and 4 as bases for withholding voluntarily submitted documents. ${ }^{132}$ The Second Circuit analyzed the issue under Exeinption 3 and did not address Exeinption 4 directly. Iniplicit in its discussion of the FTC Act, ${ }^{133}$ however, are the same issues underpinning the trade secret and coininercial information exeinption. ${ }^{134}$ The court interpreted the FTC Act directly, refusing to take a position as to whether withholding statutes should be construed narrowly or deferentially and choosing instead to look "to the plain language of the statute and its legislative history, in order to determine legislative purpose." 135

The court rejected the argument that the statute defines "voluntarily" narrowly, explaining that "[t]he statute cannot be read to turn on whether inaterial submitted voluntarily was so provided because compulsory process was a 'viable possibihty." "136 The flaw with this analysis, according to the court, was that "[s]uch a vague and amorphous formulation would create needless difficulties for the courts that would be obliged to apply it."137 The alternative analysis was equally unacceptable to the court, which

130. Id. at 141 .

131. Id.

132. Id. at 142 .

133. The FTC Act provides in relevant part:

Any material which is received by the Commission in any investigation, a purpose of which is to determine whether any person may have violated any provision of the laws administered by the Commission, and which is provided pursuant to any compulsory process .... or which is provided voluntarily in place of such compulsory process shall be exempt from disclosure under section 552 of title 5.

15 U.S.C. § 57b-2(f) (1988).

134. The FTC Act here operates as an exemption substitute in the same way as statutes tike the CIA Information Act, 50 U.S.C. $\S 431$ (1988), and the National Security Act, 50 U.S.C. $\S 403(\mathrm{~g})(1988)$, serve as additional bases for claims of exemption under the analysis in Part I. The FTC Act articulates the same foundation for nondisclosure as FOIA's Exemption 4, and thus the analysis is comparable under either Exemption in this circumstance.

135. A. Michael's Piano, 18 F.3d at 144.

136. Id.

137. Id. 
stated that the district court's ruling "that all voluntarily submitted documents were exempt" was too sweeping in its nondisclosure. ${ }^{138}$ Criticizing the lower court's ruling for denying public access to information deeined to be irrelevant to the investigation or outside the scope of the agency's ability to compel production of documents, the appellate court declared that "[s]uch broad exemption creates too lieavy a cloak of gratuitous secrecy."139

The court then turned to the legislative listory of the FTC Act, concluding that "while it is true that the confidentiality provision of the FTC Act was intended to encourage disclosure to the FTC by businesses, it is also true that Congress did not intend to create a broad exemption that would effectively eliminate the FTC's accountability to the public." ${ }^{140}$ Thus, the FTC does not create additional FOIA exemptions to the extent that the CIA Information Act does. As additional evidence, the court quoted statements made by Senator Cannon explaining the need for the bill to end agency abuse of its authority: "The FTC lost sight of the necessity to listen to the evidence and legal arguments of its opponents. Good judgment and wisdom had been replaced with an arrogance that seemed unparalleled ainong independent regulatory agencies" 141 - tliougl not perhaps when compared to the CIA's positions discussed above. Thus, the court concluded that Congress could not liave "aimed to curtail the FTC's exercise of its autlority and at the same time provide it witl a blanket exemption froin FOIA for all documents submitted to it voluntarily." 142

Ratlier, tlie court proposed a new test:

[W] think a workable standard is one that permits the FTC properly to invoke $\S 21(\mathrm{f})$ by showing that (1) it had requested documents that were (2) relevant to an ongoing investigation within its jurisdiction and (3) the documents could have been subpoenaed had the party refused to comply with the FTC's requests. ${ }^{143}$

The court then remanded the matter to the district court for an application of this test, allowing the lower court to reconsider its

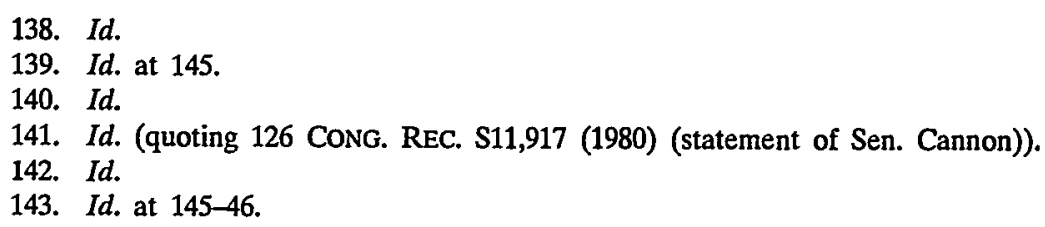


earlier result of "inadvertently limited public disclosure . . . "144 Thus, the court furtler complicated confidential commercial information analysis under FOIA by inserting anotlier test to determine the propriety of FOIA disclosure. In articulating this new test, moreover, the court failed to account for the diminished public interest at stake when a business adversary inamipulates FOIA's mechamism to obtain otherwise confidential trade secrets.

In an even inore recent discussion of proper Exemption 4 analysis, the court in GC Micro Corp. v. Defense Logistics Agen$c y^{145}$ required disclosure in an Exemption 4 case mvolving records documenting several federal defense contractors' use of small disadvantaged businesses. In GC Micro, the Mexican-American owner of a sinall hardware and software distributor suspected that government contractors were failing to coinply with subcontracting goals enunciated by the Small Business Act. ${ }^{146}$ The Small Business Act establishes annual minimum goals for participation by small disadvantaged businesses (SDBs) in procureinent contracts, including a requirement that no less than $5 \%$ of all contracts and subcontracts go to SDBs. ${ }^{147}$ To ensure coinphance, contractors are mandated under the Act to file reports detailing their participation in the Act's goals. ${ }^{148}$

GC Micro alleged that Hercules Aerospace refused to contract with it or any other SDB and therefore requested information froin the Defense Logistics Agency regarding the impleinentation and attamment of SDB goals. The requestor argued that ascertaming coinpliance is significant because "[i]t's a good selling tool ... to go into these contractors, target the ones that aren't meeting [the goals, and] go in and lielp them meet their goal."149 After obtaining this information, GC Micro then requested disclosure of additional information relating to contracts between the Department of Defense and Loral Aerospace, McDoimell Douglas Corporation, and Northrop Corporation. Specifically, the information deinanded consisted of the inost recent filings of two particular forms: a quarterly summary report of compliance with SDB sub-

144. Id. at 146.

145. 33 F.3d 1109 (9th Cir. 1994).

146. See 15 U.S.C. $\$ 637(a)(1)(B)$ (Supp. IV 1992).

147. Id. § 644(g)(1) (1988).

148. Id. $\S 644(\mathrm{~h})(1)$.

149. GC Micro, 33 F.3d at 1111 (quoting the district court record). 
contracting goals, including all contracts between the subject company and the government, and a semiannual contract-specific report of the estinated and actual subcontract dollars and the SDB goals by dollar amount as well as percentage. ${ }^{150}$

The Defense Logistics Agency notified the corporations whose records were in question and allowed them to object formally to disclosure. The compames did not object to allowing GC Micro to review the summary reports but refused to allow the more detailed reports on the grounds that "this information was confidential and ... that its disclosure would likely cause them substantial competitive harm." ${ }^{\text {"51 }}$ The DLA then followed these guidelines, withholding only the contract-specific financial reports under FOIA Exemption 4. Although the withheld reports did imclude information about estinnated and actual dollars spent on SDB contracts as well as other subcontracts, they did not detail "how the contractor is subcontracting the work, [or] ... the subject matter of the prime contract or subcontracts, the number of subcontracts, the items or services subcontracted, or the subcontractors' locations or identities."152 After GC Micro filed suit to obtam the information contained in these reports, the district court granted summary judgment in favor of the DLA, finding that the data was confidential under Exemption 4..$^{153}$

On appeal, the Ninth Circuit reversed. Applying the National Parks test to determine confidentiality, ${ }^{154}$ the court concluded that the documents were not properly classified as confidential. ${ }^{155}$ GC Micro persuaded the court that disclosure would advance congressional intent to augment SDB participation in government contracts. ${ }^{156}$ The court rejected the DLA's argument that the information contained within the summary reports constituted all information required to ascertain compliance. ${ }^{157}$ Significantly, the court rejected the DLA's assertion that the purpose behind the request was irrelevant to a determination of confidentiahty under

150. Id.

151. Id.

152. Id.

153. Id. at 1112.

154. See supra text accompanying note $9 !$.

155. GC Micro, 33 F.3d at 1115.

156. Id. at 1113 .

157. Id. 
Exemption $4 .{ }^{158}$ The court emphasized that under the objective National Parks test for confidentiality, "whether the information is of a type which would normally be made available to the public, or whether the government has promised to keep the information confidential, is not dispositive under Exemption 4." 159 In particular, the court explained that disclosing the information contained in the reports "would enable 'the public to evaluate the wisdom and efficiency of federal programs and expenditures,' as well as an executive agency's compliance with federal law."

In considering the nature of the evidence proffered by DLA to support its claim of confidentiality, the court reiterated the estabhished rule that "evidence revealing (1) actual competition and (2) a likelihood of substantial competitive injury is sufficient to bring commercial information under Exemption 4."161 As evidence, the DLA included declarations by its officers to the effect that disclosing the reports would harm "the corporations' competitive positions because it would provide competitors with a roadmap of the corporations' subcontracting plans and strategies."162 Specifically, the conipanies argued through the DLA that their competitors could use detailed profiles of the use of small businesses in subcontracts to "win contracts away from them by promising the DLA that they would subcontract to a greater percentage of SDB's than the three contractors had in the past." 163

GC Micro countered with the argument that the information comprising the reports is much too general and contains "too many fluctuating variables for conipetitors to gain any advantage from ... disclosure."164 The court agreed with GC Micro, concluding that

despite the rather conclusory statements made by ... [the] defense company executives, the DLA has failed to show how analysis of the data listed ... would provide competitors with a profile of exactly how a defense contractor conducts its business

158. Id.

159. Id.

160. Id. (quoting Racal-Milgo Gov't Sys., Inc. v. Small Business Administration, 559 F.

Supp. 4, 6 (D.D.C. 1981)).

161. Id.

162. Id. at 1114.

163. Id.

164. Id. at 1115 . 
with regard to the use of SDB's in various types of government contracts. ${ }^{165}$

The court stressed that data on the percentage and dollar amount of work subcontracted out to SDB's on each defense contract "would provide little if any help to competitors attempting to estimate and undercut the contractors' bids."166 Thus, although there is no mandate that the DLA "engage in a sophisticated economic analysis of the substantial competitive harm to its contractors that might result from disclosure," theless adduce enough proof of a potential of substantial competitive harm.

The court concluded that this burden had not been met and thus "that FOIA's strong presuinption in favor of disclosure trumps the contractors' right to privacy." DLA's evidence, the court noted that "[i]t is questionable whether the declarations submitted by the three contractors show any potential for competitive harm, let alone substantial harm."169 The court insisted on its conclusion because "Congress did not pass Exeinption 4 to protect large corporations froin persistent coinputer salespeople."170 On the other hand, Congress certamly did not enact FOIA as a means for businesses to find out more information about industrial competitors without some check on the use of that information. Once again, the court disregarded the central goal of FOIA: the ability for the public to gain access to governmental records in order to achieve fuller democratic self-rule. While GC Micro caine closer to inquiring about the actual workings of governmental regulatory agencies than did the FOIA requestor in A. Michael's Piano, the courts in both cases failed to interpret FOIA in light of its overriding purpose.

165. Id. at 1114-15.

166. Id. at 1115.

167. Id.

168. Id.

169. Id.

170. Id. 


\section{REMEDYING THE ABOVE CRITICISMS}

A. The Need for Accommodating the Guiding Purpose of FOIA in Balancing Analysis

The difficulty in reconciling the courts' treatment of the cases discussed above lies in their failure to fully consider the guiding purpose of FOIA when balancing interests as mandated by these cases. The first step in forging a more coherent FOIA jurisprudence is to accommodate the central purpose of the Act in all FOIA analysis. Consideration of the reasons for FOIA's existence should comprise an element of any test or discussion of a challenged FOIA request. The problem inherent with the courts' creation of a near-blanket exemption for the CIA is that it thwarts the very reason for FOIA's existence-access to otherwise unobtainable governmental information essential to the process of democratic self-rule by an informed electorate. When the Agency has the ability to determine conclusively its own exemption from disclosure, the "people who mean to be their own Governors" cannot "arm theinselves with the power which knowledge gives." 171 The problematic aspect of the courts' analysis under Exemption 4 is that it achieves precisely the opposite result and this ignores FOIA's purpose. Instead of distorting the fundamental purpose of FOIA by failing to provide meaningful review of exemption claims, the courts achieve the same result by compelling disclosure of information when the guiding purpose of FOIA does not sanction it.

Disclosure of the private information at issue in the Exeinption 4 cases discussed above relates in no way to the ability of the citizenry to inform itself about governmental affairs. Rather, the cases were brought by other business organizations seeking confidential financial information belonging to their competitors that the government happens to be safeguarding. By compelhing these documents to be shared with the public, the courts again contravene the basic principle of FOIA-access to governmental information in order to promote viable democratic self-rule. Thus, the courts have strayed to both extremes in their misinterpretation of FOIA; they have sanctioned the withholding of properly disclos-

171. Letter from James Madison to W.T. Barry, supra note 3. 
able information by the CIA, and they have mandated disclosure of confidential business information when it is not warranted by Exeinption 4.

The Supreme Court specified the fundamental purpose of FOIA with precision in Department of Justice v. Reporters' Committee for Freedom of the Press, ${ }^{172}$ stating that the public interest at stake in FOIA cases and indeed the reason for the Act's existence is "the citizens' right to be informed about 'what their government is up to." "173 Under this formulation, the court suggested that FOIA analysis is appropriate for those requests in which a plaintiff acting in her capacity as a citizen demands access to governmental documents relevant to the process of self-government. This standard seens to preclude the bizarre results under Exeinption 4 analysis in which a private business competitor co-opts the FOIA inechanisin of access for his personal gain without accruing any benefit to the public's need for knowledge. Furthermore, by articulating the primacy of the concern about public access to vital governmental information, this formulation by the Court suggests a different result in CIA cases as well. In the context of CIA-FOIA requests, the principle behind FOIA's enactinent is genuinely at issue. Access to information about foreign affairs falls squarely within the scope of what citizens need to learn to determine "what their government is up to." The remaining text of FOIA is not rendered void by this interpretation, of course. Proper exemptions, if analyzed with neaningful judicial review, may be appropriate to shield sensitive national security secrets from devastating public disclosure. Meaningful judicial review would demand greater factual specificity in Agency affidavits, an articulation of the specific harm posed by disclosure, increased use of in camera inspections, and a generally inore rigorous approach to the difficult task of balancing the coinpeting interests. By emphasizing the relevance of this information to the fundamental purpose of FOIA, the courts would avoid thwarting the expressed will of Congress by creating a near-blanket exemption for the CIA. ${ }^{174}$ By looking to the rea-

172. 489 U.S. 749 (1989).

173. Id. at 773 (citations omitted).

174. A change which would ehminate such a disastrous result is particularly necessary in light of the court's extraordinary acknowledgment in Hunt that "we are now 'only a short step [from] exempting all CIA records' from FOIA . . . [and] [t]hat result inay well be contrary to what Congress intended." Hunt v. ClA, 981 F.2d 1116, 1120 (9th Cir. 1992) (quoting the district court decision). 
sons for engaging in the analysis in the first place, the judicial role in FOIA jurisprudence could become more principled, and a better balance could be struck between the competing interests inherent in FOIA and its exemptions.

\section{B. Suggestions for Reform in the CIA Context}

Under this approach, the first inquiry should be whether disclosure of the requested information would further FOIA's fundamental purpose in a meaningful way. This question is particularly apt in a CIA case because the records at issue often directly affect the electorate's ability to be informed about its government's activities. Next, courts inust tailor their analyses to the specific exeinptions at issue. Particularly in the context of the CIA, the courts must not only incorporate the fundamental purpose of FOIA in their analysis, but in hight of this purpose, they also inust engage in genuinely substantive review of the issues. If FOIA's purpose would be furthered by granting the request, the court must then evaluate the Agency's claims for exeinption.

In so doing, the court inust engage in considered review and must deinand factual specifics to the greatest extent possible froin the CIA. It is inappropriate for a court like the one in Hunt to accept the Agency's own conclusion without explaining with rea-

In addition to the Court's expression of the fundamental public interest at stake in FOIA in Reporters' Committee, a recent article expounds in greater depth on the central purpose of FOIA. The authors also argue that the fundamental purpose of FOIA needs to be accommodated in judicial analysis of these cases: "The government tramples the privacy rights and confidential interests of individuals and organizations when it coinplies with requests seeking information about private citizens and organizations, rather than about the government." Fred H. Cate, et al., The Right to Privacy and the Public's Right to Know: The "Central Purpose" of the Freedom of Information Act, 46 ADMIN. L. REV. 41, 65 (1994). Also sigmificant in this article is the discussion of a tripartite structure to FOIA's fundamental purpose:

FOIA is intended to provide the citizenry with the knowledge necessary to govern. Although there is no single statement in the Act's legislative history of the necessary extent of that knowledge, it is clear that Congress envisioned at least three roles of the electorate for which the Act was designed to guarantee access to government information. First and most important, the FOIA plainly facilitates the watchdog function of the public over the government: The public Inust have access to the government information necessary to ensure that government officials act in the public interest. ... Second,... the FOIA was intended to assure the public's access to government information concerning public policy.... Third, the authors of the FOIA wanted to ensure that the government would not secretly create or enforce laws or administrative regulations.

Id. at 42 . 
sonable factual specificity the grounds for its refusal. Courts should require a higher factual basis in the Agency's assertion of exemption. In order to make these often difficult determinations, courts nust be provided with a mininum level of detailed information-at least for their own review in camera-to evaluate the issue effectively. This higher standard would not compromise the Agency's interest in secrecy because it does not require disclosure of genuinely sensitive information. Rather, it requires only a genuine factual basis for the CIA's conclusion, something lacking in recent decisions.

It is inappropriate for a court to be so deferential to the Agency's determination that the conclusion is clearly contrary to Congress's intent in enacting FOIA. The courts must be accountable to congressional intent. It is unnecessary-and would be quite extraordinary-to require Congress to anend FOIA to effectuate public disclosure of information in appropriate cases. Courts may properly defer to the CIA's judgment in matters going to the heart of national security issues because of the Agency's superior knowledge. That deference, however, has deviated from a respect for another branch's superior ability to assess potential danıage of disclosure to a near absolute abdication of judicial review.

These suggestions for a jurisprudence that is more consistent with FOIA's guiding purpose are derived from the architecture of the statute itself. The design of FOIA with de novo review and carefully delineated exceptions to the presumptive rule of disclosure already requires the Agency to act in compliance. Congress cannot be required to amend the Act snnply to express that it meant what it said in the first place. With correctly drafted Vaughn affidavits, judiciously requested in camera review of challenged information, and substantive review by the courts, judges would be better able to make the careful decisions that FOIA requests for CIA documents demand of then. It seenıs impossible that genuine review by the courts would result in acquiescence to the Agency determinations in every case, as currently exists. Neither is there reason to beheve that the CIA would be required to conipronise genuinely sensitive information that reveals intelligence sources and nethods. The plain language of FOIA Exemption 1 and the statutes qualifying under Exeniption 3 preclude such a breach of security, especially when coupled with a considered and principled analysis of the fundamental purpose of FOIA and the countervailing imterests at stake. 


\section{Suggestion for Reform in the Confidential Commercial Infor- mation Context}

In the context of FOIA's exemption of confidential commercial information from disclosure, it is imperative that courts clarify and unify their analyses to prevent the recurrence of the erratic and unprincipled results of recent cases. The National Parks test ${ }^{175}$ needs to be reworked in a ineaningful way so as to better comport with the guiding purposes of FOIA. Just as in the CIA analysis, the first step in a new framework for Exemption 4 cases requires consideration of the fundamental purpose of FOIA's enactınent. The central purpose of the Act, the ability of the electorate to keep itself informed about key governmental activities, should form the cornerstone of the analysis. In particular, courts assessing confidential cominercial information cases need to apply a more detailed standard gauging the reasons for the government's possession of the data in question.

The voluntary-involuntary distinction of National Parks ${ }^{176}$ is useful because it indicates two distinct roles that the government plays in this context. In the first role, the government is the passive collector of information, resembling a central repository or archive for other users (or for its own future use) more than a party with a substantial interaction with the companies. In $G C$ Micro, ${ }^{177}$ the government obtained its information in this capacity; it was simply compiling the data and not actively pursuing the information as part of an investigation. In the second role, the government is an active participant in an investigation or other proceeding involving the business information, such as the FTC investigation at issue in A. Michael's Piano. ${ }^{178}$ Only when the government is acting in its second role is the purpose of FOIA furthered by public disclosure of the information; only when pursuing the information in this active way is the electorate actually being imformed about its government's activities.

This distinction-clearer than the messy voluntary-involuntary National Parks language-is only part of the necessary inquiry. It is important to consider not only how the government obtained

175. See supra text accompanying note 91 .

176. See supra text accompanying notes 97-98.

177. See supra text accompanying notes 145-70.

178. See supra text accompanying notes 121-44. 
the information at issue but also the related question of how the requestor intends to use the information. Other FOIA issues do not require the requestor to state grounds for approving the request, so an amendment may be necessary in this circumstance. Such an amendment would be appropriate, however, to ensure the proper use of this very sensitive-and very private-information. Requiring that the requestor's proposed use of the information contribute to the guiding purpose of FOIA would prevent FOIA from being used as a tool in industrial espionage. Granting the request in that case did nothing to further the electorate's ability to inform itself about the workings of its government. The information was purely private in nature and the motive behind the request--essentially industrial espionage-did not advance the public's ability to know what its government was doing. Instead, the request in that case completely co-opted the FOIA mechanism for private gain. An amendment requiring the requestor to state appropriate grounds for the demand for disclosure would eliminate this danger and would keep confidential information out of the hands of those intending to use it for improper purposes. In the absence of such an amendinent, the courts must heighten the scrutiny of these requests and adhere as closely as possible to the fundamental purpose of FOIA in determining whether disclosure is proper when requested. The government's interest in a continuing ability to obtain this information and the supplier's interest preventing substantial harm to its competitive position-the interests outlined in the original text of National Parks ${ }^{179}$-must still be protected. In so doing, however, courts should consider the role of the government inquiry and the purpose of the request instead of the murky voluntary-involuntary analysis.

\section{CONCLUSION}

Recent FOIA jurisprudence demonstrates the Act's-or at least its enforcers'-failure to accommodate successfully the conflicting public right to access and the governmental and private rights to privacy. The theoretical underpinming of FOIA has been distorted by its proponents, critics, and manipulators alike. Instead of forging a new mechanism by which American democratic selfrule can achieve fuller realization, the courts in their patchwork

179. See supra text accompanying note 91 . 
analysis have only contributed to FOIA's inefficacy. In spite of the lofty rhetoric trumpeted by its supporters, ${ }^{180}$ FOIA rarely contributes to the awareness of the electorate. Particularly in the areas of national security information and commercial trade secrets, the courts have not been able to articulate standards of administration that adequately further congressional intent behind FOIA. With near complete judicial abrogation of responsibility in cases where the CIA challenges disclosure and with increasingly convoluted rationales and results im cases where confidential commercial and fimancial imformation are at issue, FOIA's ability to achieve a workable mechanism for public access to certain governmental information has been severely impeded.

180. In a scathing attack on the cost-benefit problems of FOIA's administration, nowJustice Scalia commented: "Through the mutually reinforcing praise of many who should know better, the act is paraded about with the veneration normally reserved for the First Amendment itself." Antonin Scalia, The Freedom of Information Act Has No Clothes, REG., Mar.-Apr. 1982, at 14, 15. 
